\title{
Content Analysis of the APOS Theory Studies on Mathematics Education Conducted in Turkey and Internationally: A Meta-Synthesis Study
}

\author{
Özgün ŞEFIKK ${ }^{1}$, Özge ERDEM UZUN ${ }^{2}$, Şenol DOST ${ }^{3}$ \\ ${ }^{1}$ Hacettepe University, Ankara, Turkey, ozgun.sefik@hacettepe.edu.tr, \\ https://orcid.org/0000-0001-8680-9465 \\ 2 Hacettepe University, Ankara Turkey, ozge.erdem@hacettepe.edu.tr, \\ https://orcid.org/0000-0002-1812-0276 \\ 3 Hacettepe University, Ankara, Turkey, dost@hacettepe.edu.tr, \\ https://orcid.org/0000-0001-5762-8056 \\ Received : 08.11.2021 Accepted : 22.11.2021 \\ Doi: 10.17522/balikesirnef.1020526
}

\begin{abstract}
This study aimed to review the APOS Theory, which was developed within the context of conceptual understanding as one of the main aims of mathematics education, studies in the field of mathematics education. The studies with Turkey and international samples related to the APOS Theory were subjected to descriptive content analysis, and a systematic summary was presented. As a result of the analysis, three themes, namely the purpose of using the theory, the use of genetic decomposition, and the aim of the study were identified. There are descriptive studies (39\%) in the literature that determine the mental structures and mechanisms rather than the structure of mathematical concepts. Such studies are weak in terms of the theory's aim of reinforcing conceptual understanding.
\end{abstract}

Key words: APOS Theory, conceptual understanding, concept teaching, mathematics education.

\section{Introduction}

Conceptual understanding must be acquired in order to gain a full understanding of mathematical concepts and to ensure meaningful learning. In this context, mathematics learning theories are effective tools in interpreting students' work and needs (Trigueros \& Possani, 2013). There are two characteristics that should be present in a theory in mathematics education. First, a theory must try to understand how mathematics can be learned. Second, it should reveal what can be done to improve mathematics teaching programs (Dubinsky \& 
McDonald, 2001). One of the learning theories that has these characteristics and that was developed specifically for mathematics education is the APOS Theory.

The main aim of the APOS Theory is to reveal how a mathematical concept is structured in the mind of an individual and to develop activities pertaining to the way to be followed in teaching (Arnon et al., 2014). In other words, the main focus of the APOS Theory is to try to explain the phenomena that can be observed in students trying to build an understanding of mathematical concepts, and to present methods for the learning process to be effective (Dubinsky \& McDonald, 2001).

The APOS Theory has an important place in the development of mathematics education within the context of its own terms and phenomena. For this reason, there are many national and international studies carried out based on the APOS Theory in the literature. While the theory has so far been widely focused on in the international literature, it is seen that studies on the APOS Theory have been increasingly carried out in the national literature in the last ten years.

\subsection{The APOS Theory}

The APOS Theory proposed by Dubinsky (1984) emerged as a result of the effort to understand the reflective abstraction mechanism put forward by Piaget to describe the development of logical thinking in children and was extended to the process of structuring advanced mathematical concepts. Although the theory was developed for advanced mathematical concepts, it is also an effective theory in examining the understanding of more basic mathematical concepts such as fractions (Dubinsky \& McDonald, 2001). In addition, the theory can be characterized as a tool to explain the difficulties students experience related to mathematical concepts and to suggest ways on how students can learn these concepts (Dubinsky \& McDonald, 2001; Trigueros \& Possani, 2013).

According to the APOS Theory, while learning a mathematical concept, the individual builds mental structures named Action, Process, Object and Schema. These mental structures are formed by mental mechanisms based on reflective abstraction. According to the theory, there are five types of reflective abstraction, which are interiorization, encapsulation, deencapsulation, coordination, and reversal. For example, as the individual repeats Actions that depend on external stimuli (such as formulas), he gains Process insight through interiorization. The individual with the understanding of the Process develops an internal control over the Actions and gains an understanding of the Object through encapsulation. 
However, the understanding of the Object is the most difficult mental construct to acquire. Schema, on the other hand, is the entire cognitive structure in the mind of an individual regarding a mathematical concept (Arnon et al., 2014). For the development of Schema understanding, different Actions, Processes and Objects should be associated in the construction of new knowledge (Trigueros \& Possani, 2013). The relationships between mental structures and mechanisms related to a mathematical concept can be summarized as follows:

- Action can be interiorized into a mental Process.

- Two mental Processes can be coordinated or a Process can be reversed to construct a new Process.

- The Process can be encapsulated to create a mental Object.

- The Schema can be thematized into a mental Object (Arnon et al., 2014).

The hypothetical model that defines these mental structures and mechanisms predicted by the APOS Theory is called genetic decomposition (Arnon et al., 2014).

\subsubsection{Genetic Decomposition}

A study to be conducted within the context of the APOS Theory should have the following cyclical content:

- Theoretical analysis of a mathematical concept,

- Development and implementation of instructional practices based on this theoretical analysis,

- Collecting and analyzing data to test and organize both the initial theoretical analysis and teaching (Dubinsky \& McDonald, 2001).

This cyclical content continues until we have enough understanding of the epistemology of a mathematical concept and effective methods that will contribute to learning. In general terms, the purpose of theoretical analysis is to reveal the genetic decomposition of a mathematical concept (Dubinsky \& McDonald, 2001).

The most important component of the APOS theory is genetic decomposition, which is a teaching model consisting of mental structures and mechanisms that students can create to understand a mathematical concept (Arnon et al., 2014; Dubinsky \& McDonald, 2001; Trigueros \& Possani, 2013). Genetic decomposition that needs to be tested experimentally (Arnon et al., 2014; Trigueros \& Possani, 2013) is a hypothetical model until tested. This model guides the teaching of mathematical concepts. In summary, genetic decomposition is a 
pedagogical strategy that predicts how a concept is learned and how it can be taught (Arnon et al., 2014).

Within the context of the APOS Theory, genetic decomposition can be constructed depending on the researcher's experience in learning and teaching the concept and the knowledge of the APOS Theory, the researcher's mathematical knowledge, the literature on the concept, and the historical development of the concept (Arnon et al., 2014). The function of genetic decomposition in the APOS Theory is to explain how a concept can occur in the mind of an individual and to present what the individual's prior knowledge of the concept should be. In this context, genetic decomposition can list the reasons for the difference in students' math performance (Arnon et al., 2014). In summary, while the APOS Theory is based on the question of how a mathematical concept is structured in the mind of the individual, genetic decomposition provides the description of these mental structures and mechanisms.

\subsubsection{ACE Teaching Cycle}

According to the APOS Theory, instructional practices should be developed depending on the theoretical analysis performed to construct genetic decomposition. The purpose of these instructional practices is to design activities to help students create mental structures for a mathematical concept and to understand the relationship of these structures with the concept (Dubinsky \& McDonald, 2001). Activities designed using genetic decomposition contribute to the development of new mathematical concepts in the mind of the individual (Trigueros \& Possani, 2013). Constructivist learning environments can be designed with these activities. One of these learning environments is the ACE teaching cycle, which is specific to the theory.

ACE teaching cycle includes three components: Activities, Classroom Discussions, and Exercises. Activities designed within the context of the APOS theory are based on students' prior knowledge (Trigueros \& Possani, 2013). These activities are prepared in relation to the genetic decomposition of a mathematical concept. For example, the aim of the activities in the action phase is to guide the construction of a new concept. Activities performed to gain a process understanding further aim to help students make transformations into internalized Actions in which they can apply rules without outside help. Activities performed to acquire Object understanding aim to help students think about a Process and be aware of it as a whole so that they can apply new Actions (Trigueros \& Possani, 2013). According to the ACE teaching cycle, in the second stage, students participate in class 
discussions in collaborative groups, and finally, they continue the cyclical order by doing exercises and homework (Arnon et al., 2014).

\subsection{The APOS Theory In The Literature}

No studies have yet been conducted to evaluate how the APOS Theory is addressed in a detailed and systematic way in mathematics education research. In this study, the studies on the APOS Theory have been reviewed in terms of the handling of the topic and the general trends in order to fill the gap in the relevant literature. The way the theory has been addressed in studies can be grouped under four themes, which are the purpose of using the theory, the use of genetic decomposition, the teaching method, and the aim of the study.

\subsubsection{The Purpose of Using the APOS Theory}

The APOS Theory can be used for data analysis or as a teaching method in a study (Dubinsky \& McDonald, 2001; Trigueros \& Martinez-Planell, 2010). For data analysis, the theory is used to examine the structures formed in the minds of students after the application or teaching of a mathematical concept. As a teaching method, the theory is used to design activities for the teaching of a mathematical concept and to examine the mental structures of students after the implementation of these activities (Trigueros \& Martinez-Planell, 2010). As seen in the related literature, although the APOS Theory is mostly used for data analysis (Bansilal, 2011; Brijlall \& Maharaj, 2015; Brijlall \& Ndlazi, 2019; Chimhande, Naidoo, \& Stols, 2017; Martinez-Planell, Gaisman, \& McGee, 2017) and as a teaching method (Martin, Loch, Cooley, Dexter, \& Vidakovic, 2010; Possani, Trigueros, Preciado, \& Lozano, 2010), it is also possible to find studies in which the APOS Theory was used for both purposes (Figueroa, Possani, \& Trigueros, 2018; Maharaj, 2013; Moon, 2019; Ndlovu \& Brijlall, 2019; Trigueros \& Possani, 2013). In summary, the APOS Theory can be used for data analysis, as a teaching method, or both.

\subsubsection{The Use Of Genetic Decomposition}

Although the APOS Theory is used for different purposes (data analysis or teaching method), it is essential to include genetic decomposition for the related concept in studies (Dubinsky \& McDonald, 2001; Trigueros \& Martinez-Planell, 2010; Trigueros \& Possani, 2013). Genetic decomposition, which is the main component of the APOS Theory, can be constructed within the study or the existing genetic decomposition can be used. However, there are APOS Theory studies in the relevant literature (Hannah, Stewart, \& Thomas, 2016; Maharaj, 2015, 2018a, 2018b; Makonye, 2017) that did not use genetic decomposition.

\subsubsection{Teaching Method}


One of the main goals of the APOS Theory is to present effective teaching methods related to a mathematical concept (Arnon et al., 2014). The ACE teaching cycle is a teaching method developed specifically for the APOS Theory. In this regard, the use of the ACE teaching cycle (Figueroa et al., 2018; Ndlovu \& Brijlall, 2016; Siyepu, 2015) is common in the APOS Theory studies. However, different teaching methods can also be used in APOS Theory studies such as modeling (Possani et al., 2010), learning trajectory (Avcu \& Cetinkaya, 2019; Trigueros \& Possani, 2013), and realistic mathematics education (Deniz, 2014).

\subsubsection{Aim Of The Study}

The APOS Theory focuses on conceptual understanding and aims to develop instructional ways to achieve conceptual understanding. The aim of the APOS Theory to measure conceptual understanding is related to determining the mental structure and mechanisms of the sampling regarding a mathematical concept. However, in addition to the aim of the theory to reveal conceptual understanding (Bansilal, Brijlall, \& Trigueros, 2017; Borji \& Martinez-Planell, 2019; Maharaj, 2013), there are studies on the development of the theory (Dubinsky \& McDonald, 2001; Moll, Trigueros, Badillo, \& Rubio, 2016; Stenger, Weller, Arnon, Dubinsky, \& Vidakovic, 2008) and on developing teaching methods in the literature (Moon, 2019; Possani et al., 2010).

In the related literature, there are many national and international studies on the APOS Theory. A systematic summary of the general approaches and trends of these studies from a holistic perspective can enable both the development of the theory and the identification of the needs for future research. When the literature is examined, it is seen that there is one study (Bayraktar, Tutak, \& Illhan, 2019) that examines the studies on the APOS Theory in terms of document analysis and no meta-synthesis research has been found.

The aim of this study is to review the studies on the APOS Theory. In this context, the research problem is "What is the current status of the APOS Theory studies in the field of mathematics education?". Accordingly, the sub-research questions are as follows:

1. How are the APOS Theory studies with a national sample distributed in terms of research type, year, sampling, research method, qualitative research design and the learning area? 
2. How are the studies with a national sample distributed in terms of the purpose of using the APOS Theory, the use of genetic decomposition, the teaching method, and the aim of the study?

3. How are the APOS Theory studies with an international sample distributed in terms of research type, year, sampling, research method, qualitative research design and the learning area?

4. How are the studies with an international sample distributed in terms of the purpose of using the APOS Theory, the use of genetic decomposition, the teaching method and the aim of the study?

\section{Method}

In this study, the descriptive content analysis and thematic content analysis methods (meta synthesis) were used in order to review the studies on the APOS Theory in the field of mathematics education. Based on the main concepts of the theory, the available studies were examined under various categories, the general approaches were determined, and systematic analyses were conducted by trying to reveal the deficiencies that could lead to a new research topic.

\subsection{Data Collection}

The data consists of a total of 125 studies, including 18 theses and 107 articles, published between 2000 and 2020, focusing on the APOS Theory in mathematics education. The distribution of the types of the studies with national and international samples is given in Graph 1.

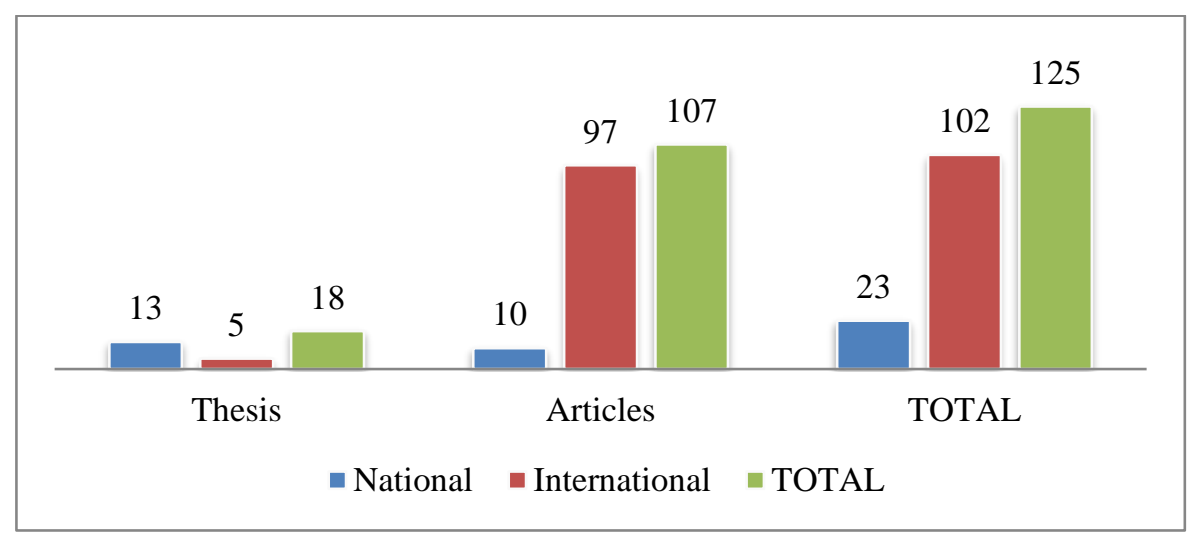

Graph 1. The distribution of the studies according to research type 
Web of Science (WOS), ERIC, Yöktez and Dergipark databases were scanned three times to obtain the data of the study. The search was made using the keywords "apos theory" and "apos AND mathematics" in WOS and ERIC databases, and using the keywords "apos" in the Yöktez database and "apos AND mathematics" in the Dergipark database. In addition, the accuracy of this data was checked by searching with the keyword "APOS theory" in Google Scholar. If a thesis and an article belonged to the same author, the thesis has been included in the study. If the thesis was not accessible, the article was used in the study. In addition, the studies in the form of papers were excluded from the study by the researchers with the thought that they do not include sufficient data.

In this study, a Data Collection Tool Form (Table 1) was prepared for both descriptive and thematic content analysis, considering the way the APOS Theory has been addressed in the literature.

Table 1

Data Collection Tool Form

A. INFO ON THE STUDY

\begin{tabular}{ll}
\hline Research Type & Article [ ] \\
& Master's thesis [ ] \\
& PhD thesis [ ]
\end{tabular}

Year of publication

Title of the study

Author(s)

B. RESEARCH QUESTION

C. SUB-RESEARCH QUESTIONS

D. AIM

E. FINDINGS

F. SAMPLING

Secondary School ( )

Sample size

Necatibey Eğitim Fakültesi Elektronik Fen ve Matematik Eğitimi Dergisi

Necatibey Faculty of Education, Electronic Journal of Science and Mathematics Education 


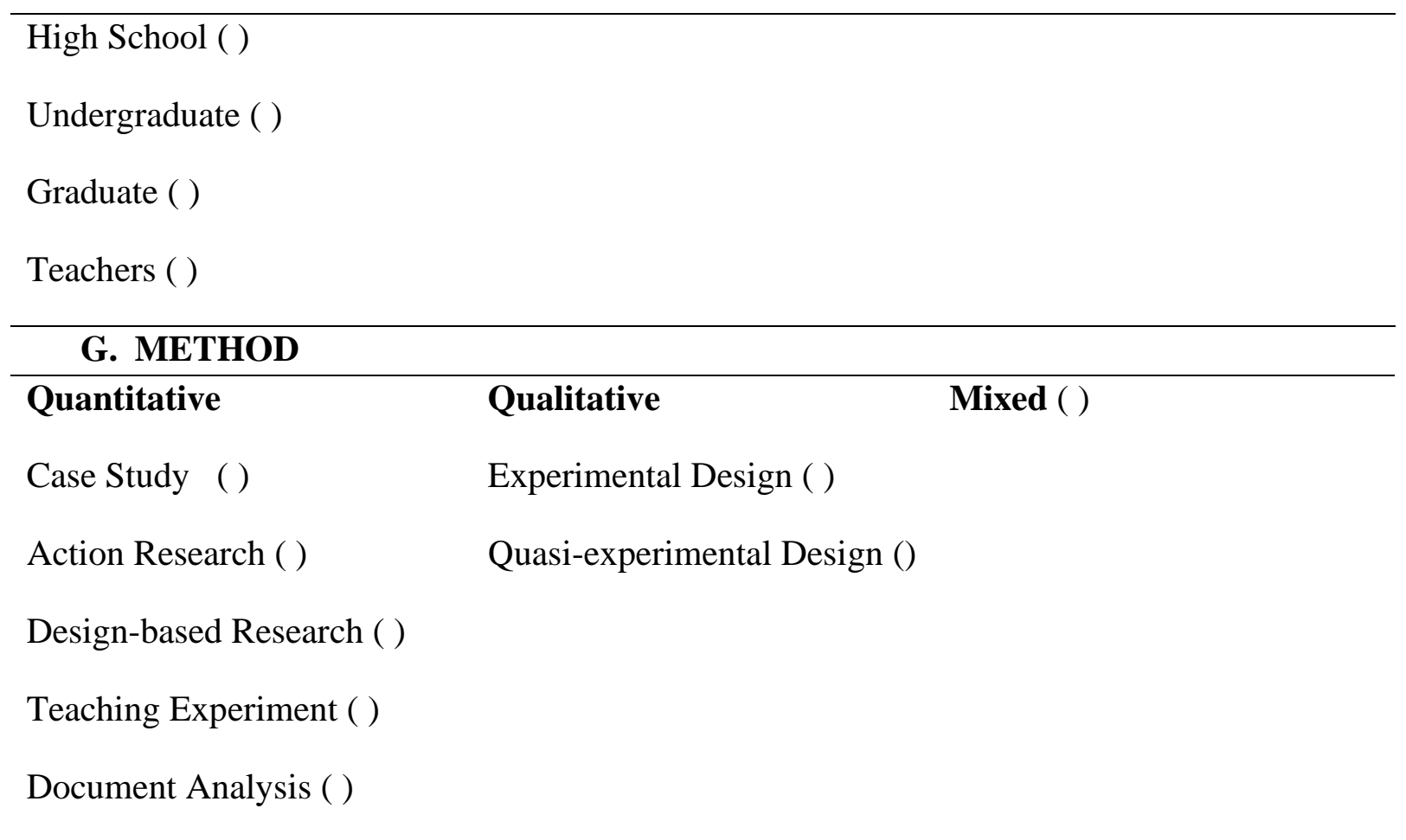

\section{H. LEARNING AREA}

\section{PURPOSE OF USING THE J. THE USE OF GENETIC THEORY DECOMPOSITION}

For data analysis ( ) Constructed within the study ( )

As a teaching method ( ) Used the existing genetic decomposition ( )

Both ( ) Not used ( )

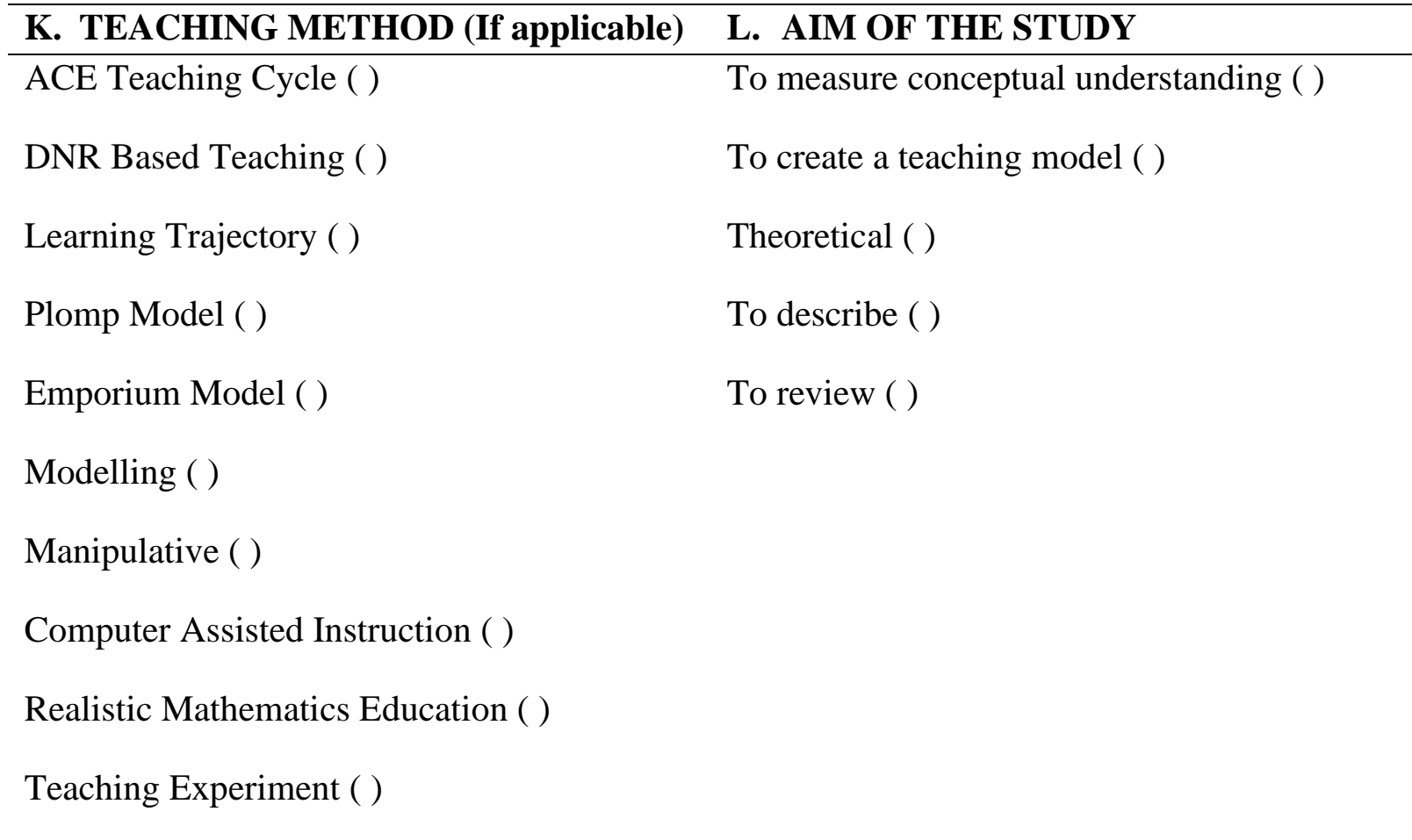


Activity Based Learning Approach ( )

Problem-Based Teaching ( )

Each study constituting the data of our study was examined based on the data collection tool form, and the analyses were conducted as described below.

\subsection{Data Analysis}

While analyzing the data, firstly descriptive content analysis was conducted, and then, thematic content analysis was performed to analyze the data in depth (Au, 2007; Çalık \& Sözbilir, 2014).

While performing the descriptive content analysis, data such as the type of research used in the study, publication year, having a national or an international study, sampling, research method, and the learning domains were taken into consideration, and descriptive statistics of these data were determined.

In the thematic content analysis, considering the ways in which the APOS Theory is addressed in the literature, three main themes were determined, which are "the purpose of using the theory", "the use of genetic decomposition" and "the aim of the study". The first two of these themes were created to address the existing APOS Theory in the literature. The theme of "the aim of the study" was determined by the authors of this study based on the data.

Information on the context in which these themes and sub-themes were created is given in Table 2.

Table 2

Brief explanations on the themes and sub-themes created in the study

\begin{tabular}{ccc}
\hline Themes & Sub-themes & \multicolumn{1}{c}{ Explanation } \\
\hline $\begin{array}{c}\text { The purpose } \\
\text { of using the } \\
\text { theory }\end{array}$ & For data analysis & $\begin{array}{l}\text { Analyzing data using mental structures and } \\
\text { mechanisms in the APOS Theory }\end{array}$ \\
& As a teaching method & $\begin{array}{l}\text { Using the APOS Theory as a teaching method } \\
\text { with the ACE teaching cycle and genetic } \\
\text { decomposition of the concept }\end{array}$ \\
\hline
\end{tabular}




\begin{tabular}{|c|c|c|}
\hline & Both & $\begin{array}{l}\text { Analyzing the results in accordance with the } \\
\text { mental mechanisms and structures in the theory } \\
\text { using the APOS Theory, using the genetic } \\
\text { decomposition of a concept and the ACE cycle, } \\
\text { and implementing a teaching method }\end{array}$ \\
\hline \multirow{3}{*}{$\begin{array}{l}\text { The use of } \\
\text { genetic } \\
\text { decomposition }\end{array}$} & $\begin{array}{l}\text { Constructed within the } \\
\text { study }\end{array}$ & $\begin{array}{l}\text { Establishing the genetic decomposition of a } \\
\text { concept through the study }\end{array}$ \\
\hline & $\begin{array}{l}\text { Used the existing genetic } \\
\text { decomposition }\end{array}$ & $\begin{array}{l}\text { The use of the existing genetic decomposition of } \\
\text { the concept in analyzing data or creating a } \\
\text { teaching method }\end{array}$ \\
\hline & Not used & $\begin{array}{l}\text { Not using any genetic decomposition for a } \\
\text { concept }\end{array}$ \\
\hline \multirow{5}{*}{$\begin{array}{l}\text { The aim of the } \\
\text { study }\end{array}$} & $\begin{array}{l}\text { To measure conceptual } \\
\text { understanding }\end{array}$ & $\begin{array}{l}\text { Studies conducted to determine the conceptual } \\
\text { understanding of the sample about a concept }\end{array}$ \\
\hline & $\begin{array}{l}\text { To create a teaching } \\
\text { model }\end{array}$ & $\begin{array}{l}\text { Studies on teaching a concept using the APOS } \\
\text { Theory }\end{array}$ \\
\hline & Theoretical & Studies to develop the APOS Theory \\
\hline & To describe & $\begin{array}{l}\text { Studies in which the mental structures and } \\
\text { mechanisms in the APOS Theory were used as } \\
\text { themes rather than to determine the structure of } \\
\text { the concept. }\end{array}$ \\
\hline & To review & $\begin{array}{l}\text { Studies examining the research on the APOS } \\
\text { Theory }\end{array}$ \\
\hline
\end{tabular}

\section{Findings}

This section includes two parts: the findings obtained as a result of descriptive analysis and the findings obtained as a result of meta-synthesis analysis.

\subsection{Findings obtained as a result of descriptive analysis}

In this study, the distribution of the studies including national and international samples and published between 2000 and 2020 across years is given in Graph 2. 


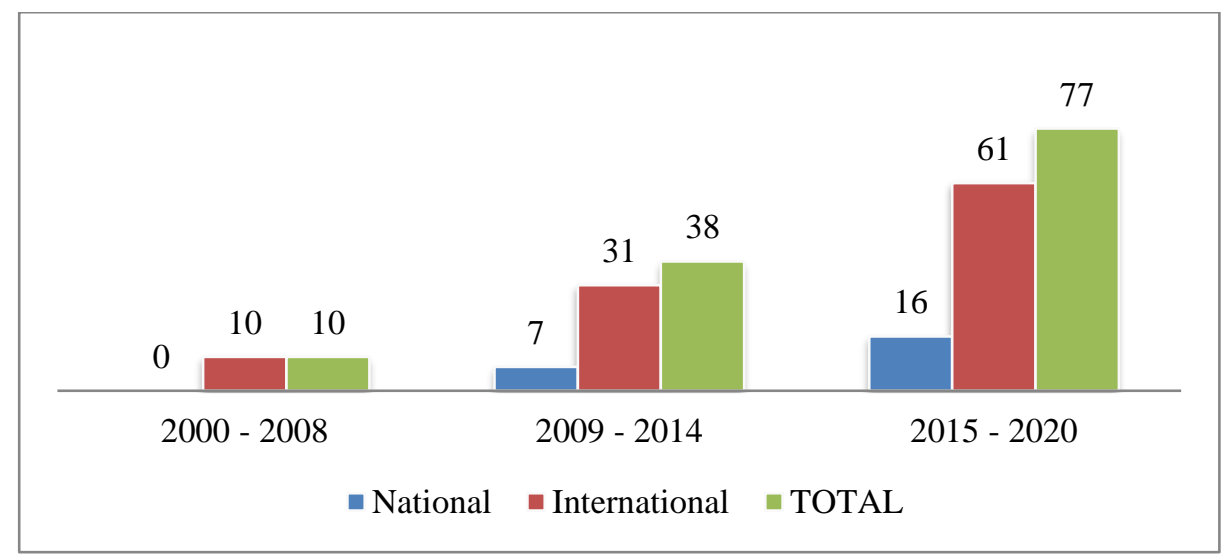

Graph 2. Distribution of the studies across years

As seen in Graph 2, studies with national samples started as of 2009. The studies conducted between 2000 and $2008(n=10)$ correspond to $8 \%$ of the total number of studies. Studies with international samples were not common before 2009. The sample of the studies was examined considering the following groups: secondary school, high school, undergraduate, graduate and teachers and was presented in Graph 3.

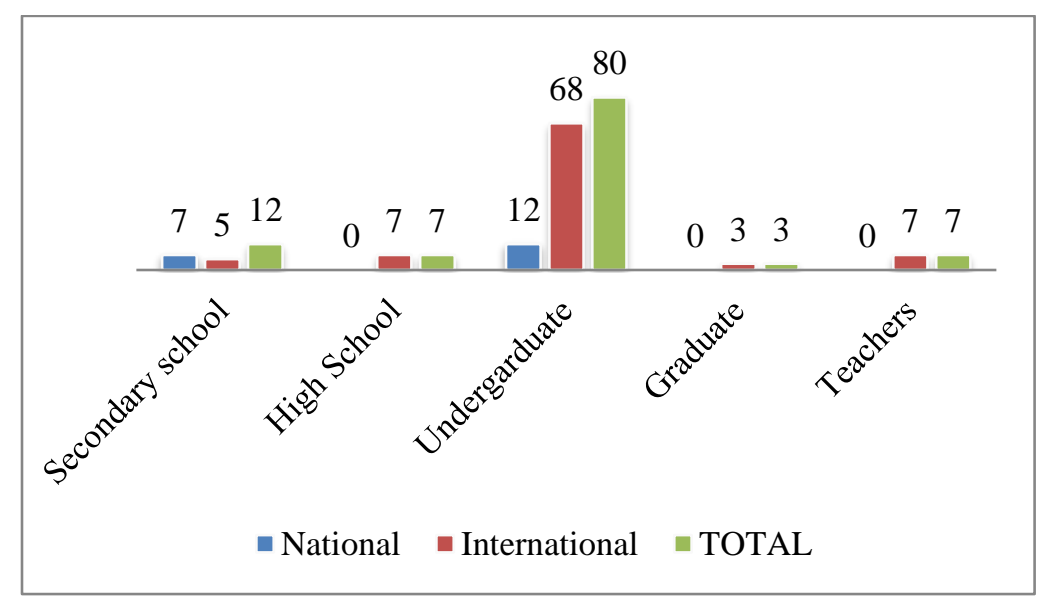

Graph 3. Distribution of the studies across sampling

When Graph 3 is examined, it is seen that $64 \%(n=80)$ of the studies were conducted with undergraduate students. In addition, while $36 \%(n=12)$ of the studies with a national sample were conducted with secondary school students, only $6 \%(n=5)$ of the studies with an international sample were conducted with secondary school students. Besides, one study was conducted with three sampling (secondary school students, high school students, and 
teachers). Some studies did not use a sampling because they were theoretical or review studies.

It is seen that the vast majority of the studies $(n=104)$ are qualitative research. There are few quantitative studies $(n=7)$ and mixed-method studies $(n=2)$. The distribution of the studies according to the research method is presented in Graph 4.

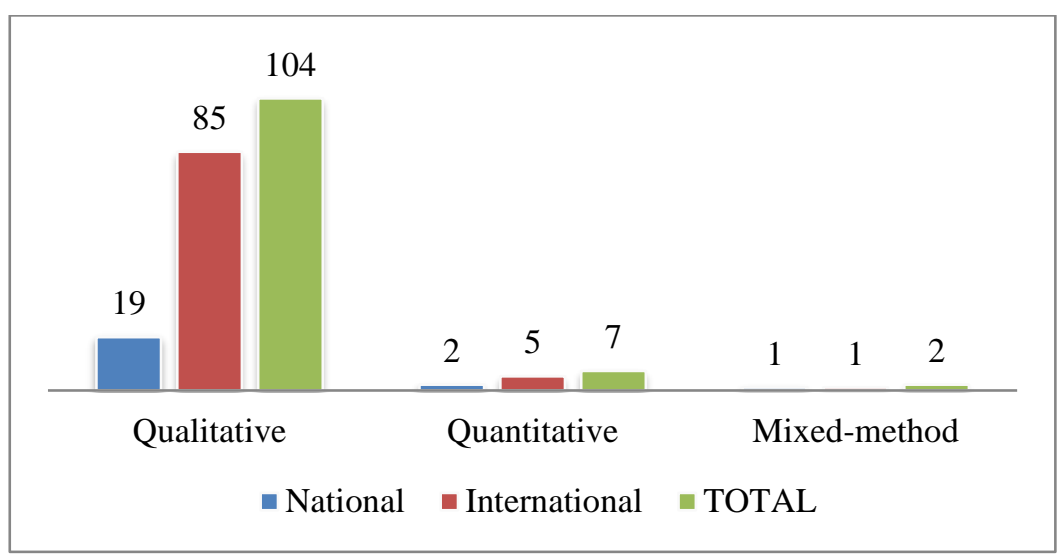

Graph 4. Distribution of the studies according to the research method

It was also observed that most of the qualitative studies $(n=91)$ are case studies. In national studies, case studies correspond to $57 \%(n=12)$ of all qualitative studies, while they constitute 93\% $(n=79)$ of all qualitative studies within international studies. Other qualitative research methods used in the reviewed studies include design-based research $(n=1)$, teaching experiment $(n=8)$, action research $(n=1)$ and document analysis $(n=3)$.

In addition, the distribution of the mathematical teaching points across different levels (secondary school, high school, undergraduate and graduate) was investigated. In this context, secondary school mathematics learning domains were determined to be "numbers and operations", "algebra" and "geometry and measurement" as given in the Ministry of National Education (MoNE) (2018a) curriculum. The distribution of the studies across the secondary school mathematics learning domains is given in Graph 5. 


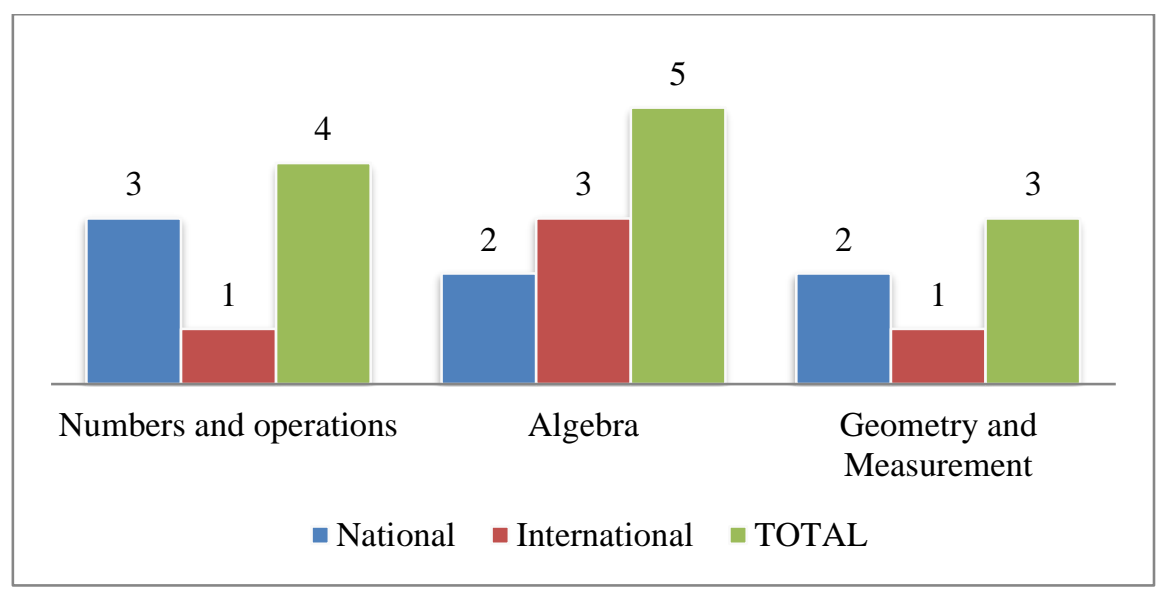

Graph 5. Distribution of the studies across the secondary school mathematics learning domains

On the other hand, high school mathematics learning domains were determined to be "numbers and algebra" and "geometry" as stated in the MoNE (2018b) curriculum. It is seen that among seven studies with international samples examining high school mathematics concepts, four studies focused on numbers and algebra and three studies focused on geometry. In addition, it is seen that studies with national samples did not include high school mathematics concepts (See Graph 3).

Undergraduate and graduate mathematics learning domains were determined to be analysis (such as function, limit, derivative, integral), algebra (such as slope, group, sets, linear algebra, matrix), geometry (such as angles, triangles, reflection, volume), and applied mathematics (such as interest rates, probability, statistics, differential). The distribution of the studies across these learning domains is presented in Graph 6.

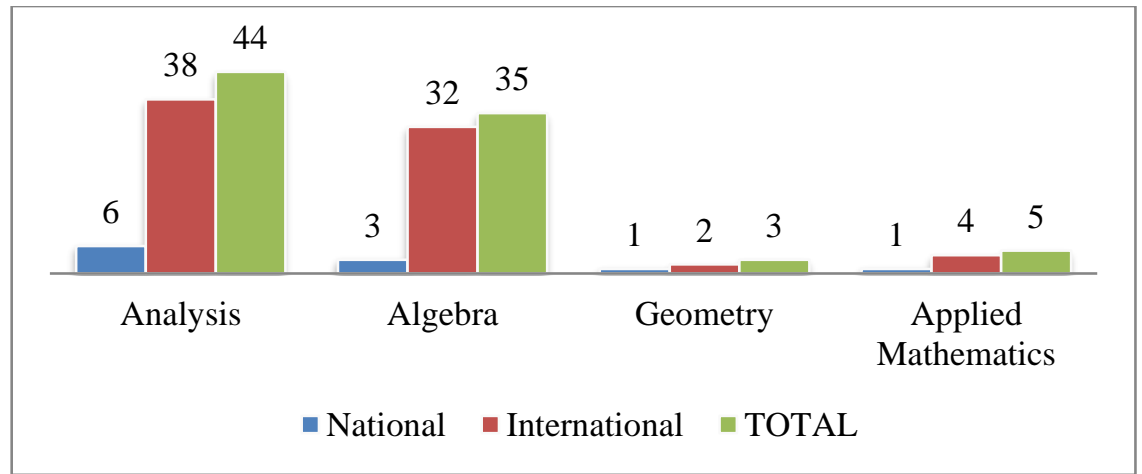

Graph 6. Distribution of the studies across undergraduate and graduate mathematics learning domains 
When Graph 6 is examined, it is seen that the majority of the studies with both national and international samples are in the fields of analysis $(n=44)$ and algebra $(n=35)$. On the other hand, one study focused on the field of computer programming, and the mental structures of the loops were analyzed.

\subsection{Findings obtained as a result of the meta-synthesis analysis}

The first of the three themes developed as a result of the meta-synthesis analysis of the studies is the purpose of using the theory. Three sub-themes were determined under this theme, which are "for data analysis", "as a teaching method" and "both" (See Table 2). In this context, the distribution of the studies with national and international samples according to the purpose of using the APOS Theory is given in Graph 7.

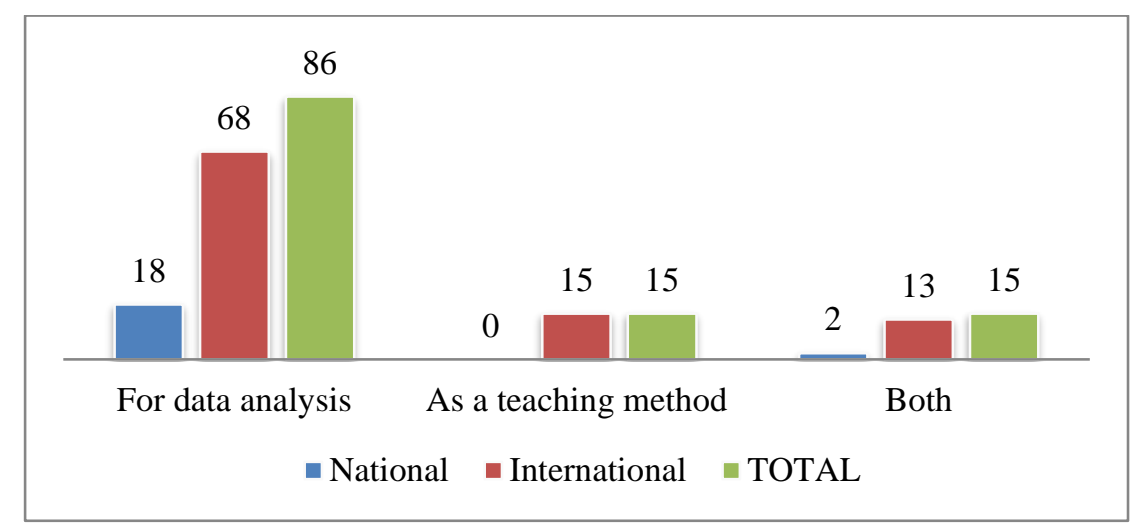

Graph 7. Distribution of the studies according to the purpose of using the APOS Theory

According to Graph 7, the majority of the studies with national samples ( $\mathrm{n}=18$, $\mathrm{f}=90 \%$ ) used the APOS Theory for data analysis, while the theory was used for data analysis in 68 studies with international samples $(\mathrm{f}=71 \%)$, as a teaching method in 15 studies $(\mathrm{f}=$ $16 \%)$, and for both purposes in 13 studies $(\mathrm{f}=14 \%)$. When all the studies are examined, it is seen that $74 \%$ of them used the APOS Theory for data analysis.

Another theme obtained as a result of the meta-synthesis analysis was "the use of genetic decomposition". Three sub-themes emerged under this theme, which are "constructed within the study", "used the existing genetic decomposition" and "not used" (See Table 2). 
The distribution of the studies with national and international samples according to the use of genetic decomposition is presented in Graph 8.

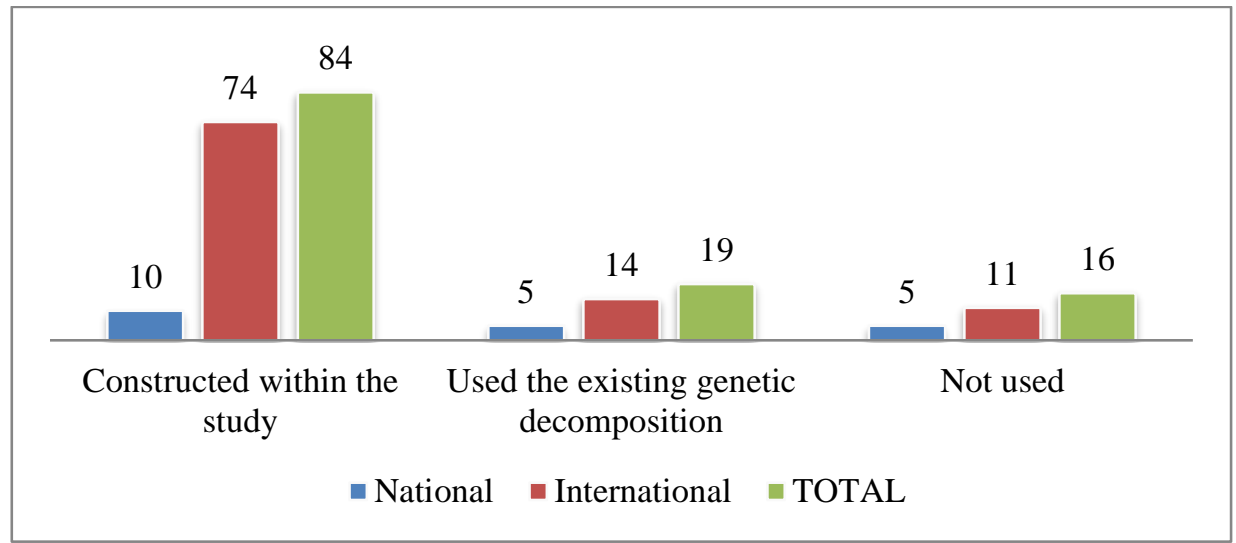

Graph 8. Distribution of the studies according to the use of genetic decomposition

According to Graph 8, genetic decomposition was constructed within the study in 50\% $(n=10)$ of the studies with national samples. In addition, $25 \%(n=5)$ of the studies did not use genetic decomposition. On the other hand, in $75 \%(n=74)$ of the international studies, genetic decomposition was constructed within the study, and it is seen that $11 \%$ of the studies $(n=11)$ did not use genetic decomposition.

Finally, the theme of "the aim of the study" was created depending on the aim of the study to use the APOS Theory. The meta-synthesis analysis revealed the sub-themes of "to measure conceptual understanding", "to create a teaching method", "theoretical", "to describe" and "to review". The distribution of the studies according to their aims is given in Graph 9.

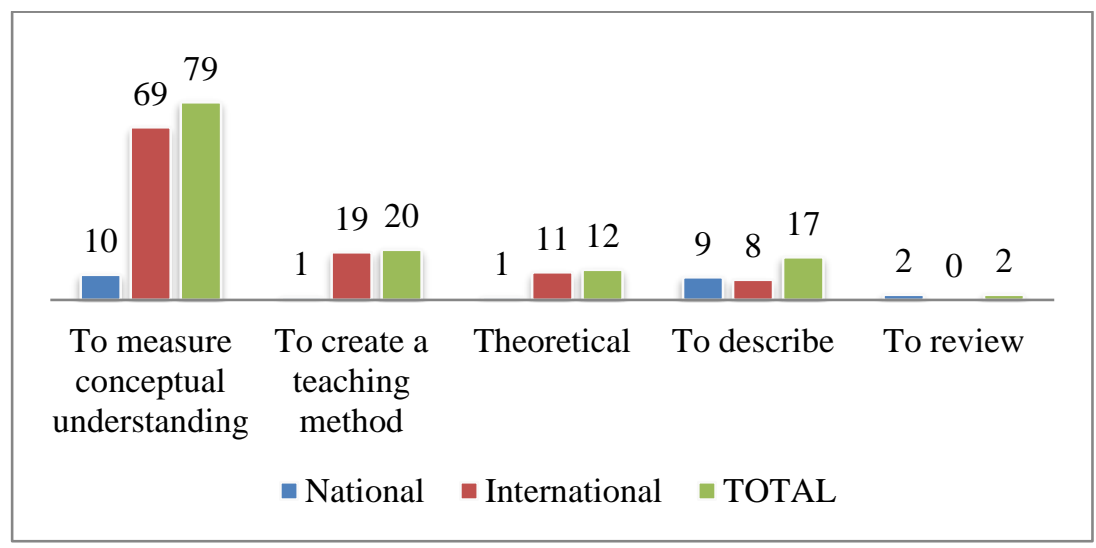

Graph 9. Distribution of the studies according to their aims 
According to Graph 9, most of the studies aim to measure conceptual understanding $(\mathrm{n}=79, \mathrm{f}=61 \%)$. In addition, the aim of the $39 \%(\mathrm{n}=9)$ of the studies with national samples was to describe. It is observed that this rate is $7 \%(n=8)$ in studies with international samples.

\section{Discussion, Conclusions and, Recommendations}

The main purpose of mathematics education is to provide opportunities for students to learn and understand mathematical concepts (NCTM, 2000). For this purpose, Principles and Standards for School Mathematics (NCTM, 2000) was prepared and the importance of concept teaching was emphasized by identifying important mathematical concepts from preschool to eighth grade (NCTM, 2014). The APOS Theory, which is based on conceptual understanding, emerged with the studies of Dubinsky in 1984, and the studies in this field increased after 2000 (See Graph 2). In Turkey, with the curriculum introduced in 2009 (MoNE, 2009), it was aimed to develop the skills of learning mathematical concepts and the relationships between concepts. Parallel to this, APOS Theory studies started with Çetin (2009)'s doctoral thesis and have increased since 2009 (See Graph 2). On the other hand, the increase in both national and international APOS Theory studies shows that the APOS Theory is an important theory in terms of concept teaching.

According to Piaget (1975), students studying at secondary school and higher levels perform actions on abstract objects, while students in primary school perform their actions on concrete objects. According to the APOS Theory, the reason for this difference is the nature of the objects to which the actions are applied (Arnon et al., 2014). In this context, the APOS Theory, which is based on Piaget's work, was developed to understand the process of structuring abstract mathematical concepts (Dubinsky \& McDonald, 2001). Considering the findings of this study, it is seen that the majority of the APOS Theory studies (64\%) were conducted with undergraduate students (See Graph 3). This finding is compatible with the 
purpose of the emergence of the theory. On the other hand, the theory can also be used for concepts at primary and secondary level (Arnon et al., 2014). As a matter of fact, according to the findings of this study, it is seen that the number of studies conducted with secondary school (11\%) and high school (6\%) students is few in the literature and has increased in recent years (See Graph 3). For example, Deniz (2014) examined 8th graders' process of constructing the concept of slope in his master's thesis. According to the study, slope is a prerequisite concept for the abstraction process of the derivative of the function, which is a preliminary mathematical concept in terms of concept hierarchy, and students encounter the concept of slope for the first time in the 8th grade. Similarly, Brijlall and Ndlovu (2013) examined 12th grade high school students' processes of structuring the maximum-minimum problems required for the derivative scheme. Accordingly, it can be said that in order to create the mental structures of high-level mathematical concepts, it is necessary to include the mental structures for pre-mathematical concepts within the context of concept hierarchy. In this sense, it can be stated that more studies should be conducted at secondary and high school levels in order to reveal the mental structures of mathematical concepts related to the theory.

It must be noted that more studies were conducted with secondary school students in Turkey (36\%). When these studies (7 in total) are examined in general, some common features stand out. These studies used the APOS Theory for data analysis and six studies used genetic decomposition, which is the most important component of the theory. In addition, one study did not use genetic decomposition and two studies used the mental structures of the APOS Theory as a theme. In summary, although there are more studies conducted with secondary school students within the national context, only $57 \%$ of these studies focused on conceptual understanding and used the components of the theory. Thus, it can be stated that although abstract relationships can be established between mathematical concepts at undergraduate level, this is not easy for secondary school mathematics concepts. It is 
observed that these studies focus on the structures established by the individual in a descriptive way rather than on the mathematical concept. Considering the historical development and abstract structure of the concepts, it can be said that there are difficulties in terms of compatibility with the level while constructing genetic decomposition for the mental structures of the mathematical concepts at the secondary school level within the context of the APOS Theory. This may be the reason why genetic decomposition was not used in studies conducted with secondary school students and why the mental structures in the theory were used descriptively.

The APOS Theory is a teaching model used to explain how mathematical concepts are learned. It is also a theoretical framework used to explain how individuals mentally construct their understanding of mathematical concepts (Arnon et al., 2014). In this context, it can be concluded that the theory focuses on the "how" question. On the other hand, case studies are studies that deal with "how" and "why" questions (Yin, 2018). Our findings revealed that the majority of the APOS Theory studies (90\%) are qualitative research and 93 percent of these qualitative studies are case studies (See Graph 4). In this context, it can be said that the aims of the theory and the case study design overlap. In addition, it has been observed that the APOS Theory studies with teaching experiment have been increasing in the last decade. For example, Harel (2017) designed a teaching experiment based on the sources of student difficulties for linear equation systems and examined how students construct knowledge. During the teaching experiment, the difficulties experienced by the students regarding the linear equation systems were determined and ideas for the development of their schemas emerged. Therefore, it can be stated that the teaching experiment designed on the basis of student difficulties overlaps with the aims of the theory in terms of making a positive contribution to concept teaching. 
The APOS Theory first focused on the concept of function (Dubinsky, 1984), which is thought to be one of the fundamental concepts of mathematics (NCTM, 1989; Ponte, 1992). It is observed that studies previously focused on basic analysis and algebra concepts. The findings of the present study revealed that the APOS Theory was mostly used in the fields of analysis and algebra (See Graphs 5 and 6). The scarcity of APOS Theory studies in the field of geometry is noteworthy. It must be noted that examining geometric transformations allows students to form the basis of a number of mathematical concepts and to improve their mathematical and cognitive skills (Clements, Battista, Sarama, \& Swaminathan, 1997; Hollebrands, 2003; Portnoy, Grundmeier, \& Graham, 2006; Yanik \& Flores, 2009). On the other hand, when the findings of the study are examined, it has been observed that although there are few studies on the concepts directly related to the field of geometry, conceptual understanding studies have been carried out on the geometric transformations of mathematical concepts such as the geometric dimension of the derivative concept and the graphical representations of functions.

The APOS Theory can be used for data analysis, as a teaching method, or for both purposes (Arnon et al., 2014). On the other hand, the theory is described as a method in important journals such as the Journal for Research in Mathematics Education of NCTM. Our findings show that 74 percent of the studies used the APOS Theory for data analysis (See Graph 7). One of the main goals of the theory is to design activities related to the path to be followed in teaching (Arnon et al., 2014; Dubinsky \& McDonald, 2001). It can be said that with this aim, the importance of using the theory as a teaching method is emphasized. However, when the findings are examined, it is noteworthy that there are few studies using the theory as a teaching method (13\%) or for both purposes (13\%). For example, Borji and Martinez-Planell (2019), who used the both purposes together, revealed the mental structures students form when taking the derivative of closed functions and designed an ACE teaching 
cycle to ensure the development of these mental structures. Such studies aiming both diagnosis and treatment are very few (only 2 studies) within the national context, which indicates the need for research in this area.

The first step of the APOS Theory studies is to investigate the epistemological structure of the concept and to construct genetic decomposition (Dubinsky \& McDonald, 2001). Genetic decomposition has two important functions: to guide the analysis of the data obtained from students and to provide a theoretical basis for designing instructional activities (Arnon et al., 2014). In other words, genetic decomposition is a bridge between the APOS Theory and its application (Trigueros \& Oktac, 2019). For this reason, genetic decomposition has an important place in APOS Theory studies. However, it is seen that genetic decomposition was not used in 13 percent of the studies examined (See Graph 8). Although the theory was used for data analysis in these studies, genetic decomposition was not used in data analysis.

The APOS Theory draws its power from mathematics in constructing mental structures related to mathematical concepts. Mathematical concepts and the relationships between concepts enable genetic decomposition to be revealed. When the findings of the present study are examined, it is seen that the majority of the studies $(61 \%)$ used the theory to measure conceptual understanding, which is compatible with the aim of the theory. However, it is seen that 39 percent of the studies conducted in Turkey used the theory to make descriptions (See Graph 9). In other words, it is noteworthy that the number of studies using the mental structures and mechanisms proposed by the APOS Theory as themes rather than to determine the structure of the concept is high within the national context. Such studies focus on the mental structures of the individual rather than the structure of mathematical concepts and use these structures as themes. In addition, it was revealed that the majority of the studies $(62 \%)$ that did not use genetic decomposition were studies that used the theory to make 
descriptions. It can be stated that studies within this scope position students' understanding of mathematical concepts according to the mental structures of the theory, but do not propose a mind map for mathematical concepts. In this context, it can be said that such studies do not have an aspect to reinforce conceptual understanding.

In sum, the APOS Theory, which emerged from the very essence of mathematics, is an important learning and teaching theory in terms of conceptual understanding. The aim of our meta-synthesis study was to reveal why the APOS Theory has an important place in mathematics education. The studies on the theory were classified according to the purpose of using the theory in mathematics education. In addition, studies with national and international samples based on the APOS Theory were reviewed and compared. In this context, the aim was to shed light on future studies by taking the studies conducted so far into account.

Türkiye'de ve Uluslararası Alanda Yapılan Matematik Ĕgitimine Yönelik APOS Teorisi Çalışmalarının İçerik Analizi: Meta Sentez Çalışması

Özet:

$\mathrm{Bu}$ araştırmada matematik eğitimi alanında yapılan, matematik eğitiminin temel amaçlarından biri olan kavramsal anlama bağlamında geliştirilen, APOS teorisi çalışmalarının mevcut durumunun belirlenmesi amaçlanmıştır. $\mathrm{Bu}$ amaç doğrultusunda APOS teorisi ile ilgili ulusal ve uluslararası örneklemli çalışmalar betimsel içerik analizine tâbi tutularak sistematik özet bilgiler sunulmuştur. Daha sonra, bu çalışmaları eleştirel bakış ile yorumlamak için meta sentez (tematik içerik analizi) yöntemi kullanılmıştır. Tematik içerik analizi sonucu; teoriyi kullanma amacı, genetik ayrışım kullanma durumu ve çalışmanın hedefi olmak üzere üç tema ortaya çıkmıştır. APOS teorisinin öngördüğü zihinsel yap1 ve mekanizmaları matematiksel kavramların yapısından ziyade bu yapıları tema olarak belirleyen betimsel nitelikli çalışmalar (\%39) alanyazında yer almaktadır. Bu türden çalışmaların APOS teorisinin kavramsal anlamayı pekiştirme amacı bakımından zayıf kaldı̆̆ı söylenebilir. 


\section{References}

Arnon, I., Cottrill, J., Dubinsky, E., Oktaç, A., Roa Fuentes, S., Trigueros, M., \& Weller, K. (2014). APOS theory. New York, Heidelberg, Dordrecht, London: Springer.

$\mathrm{Au}, \mathrm{W}$. (2007). High-stakes testing and curricular control: A qualitative metasynthesis. Educational researcher, 36(5), 258-267.

Avcu, S., \& Cetinkaya, B. (2019). An instructional unit for prospective teachers' conceptualization of geometric transformations as functions. International Journal of Mathematical Education in Science and Technology, 30. doi:10.1080/0020739x.2019.1699966

Bansilal, S. (2011). Assessment reform in South Africa: opening up or closing spaces for teachers? Educational Studies in Mathematics, 78(1), 91-107. doi:10.1007/s10649011-9311-8

Bansilal, S., Brijlall, D., \& Trigueros, M. (2017). An APOS study on pre-service teachers' understanding of injections and surjections. Journal of Mathematical Behavior, 48, 22-37. doi:10.1016/j.jmathb.2017.08.002

Bayraktar, F., Tutak, T., \& İlhan, A. (2019). An Analysis of The Studies on The APOS Theory. Electronic Journal of Education Sciences, 8(16), 242-251.

Borji, V., \& Martinez-Planell, R. (2019). What does 'y is defined as an implicit function of x' mean?: An application of APOS-ACE. Journal of Mathematical Behavior, 56, 18. doi:10.1016/j.jmathb.2019.100739

Brijlall, D., \& Maharaj, A. (2015). Exploring Pre-service Teachers' Mental Constructions When Solving Problems Involving Infinite Sets. International Journal of Educational Sciences, 9(3), 273-281. Retrieved from <Go to ISI >://WOS:000209993200002

Brijlall, D., \& Ndlazi, N. J. (2019). Analysing engineering students' understanding of integration to propose a genetic decomposition. Journal of Mathematical Behavior, 55, 12. doi:10.1016/j.jmathb.2019.01.006

Brijlall, D., \& Ndlovu, Z. (2013). High school learners' mental construction during solving optimisation problems in Calculus: a South African case study. South African Journal of Education, 33(2), 18. Retrieved from <Go to ISI >://WOS:000327851800005

Chimhande, T., Naidoo, A., \& Stols, G. (2017). An analysis of grade 11 learners' levels of understanding of functions in terms of APOS theory. Africa Education Review, 14(34), 1-19. doi:10.1080/18146627.2016.1224562

Clements, D. H., Battista, M. T., Sarama, J., \& Swaminathan, S. (1997). Development of students' spatial thinking in a unit on geometric motions and area. The Elementary School Journal, 98(2), 171-186.

Çalık, M., \& Sözbilir, M. (2014). İçerik analizinin parametreleri [Parameters of Content Analysis]. Eğitim ve Bilim, 39(174).

Çetin, İ. (2009). Students' understanding of limit concept: an APOS perspective. (Doctoral dissertation). Middle East Technical University, Ankara.

Deniz, Ö. (2014). 8. sınıf öğrencilerinin gerçekçi matematik ĕgitimi yaklaşımı altında ĕgim kavramını oluşturma süreçlerinin APOS teorik çerçevesinde incelenmesi [Examination of 8th grade students' construction of the concept of slope based on realistic mathematics education in APOS framework]. (Master Thesis). Anadolu Üniversitesi, Eskişehir.

Dubinsky, E. (1984). The cognitive effect of computer experiences on learning abstract mathematical concepts. Korkeakoulujen Atk-Vutiset, 2, 41-47.

Dubinsky, E., \& McDonald, M. A. (2001). Apos: A constructivist theory of learning in undergraduate mathematics education research. Teaching and Learning of 
Mathematics at University Level, 7, 275-282. Retrieved from $\leq$ Go to ISI >://WOS:000224702200025

Figueroa, A. P., Possani, E., \& Trigueros, M. (2018). Matrix multiplication and transformations: an APOS approach. Journal of Mathematical Behavior, 52, 77-91. doi:10.1016/j.jmathb.2017.11.002

Hannah, J., Stewart, S., \& Thomas, M. (2016). Developing conceptual understanding and definitional clarity in linear algebra through the three worlds of mathematical thinking. Teaching Mathematics and Its Applications, 35(4), 216-235. doi:10.1093/teamat/hrw001

Harel, G. (2017). The learning and teaching of linear algebra: Observations and generalizations. Journal of Mathematical Behavior, 46, 69-95. doi:10.1016/j.jmathb.2017.02.007

Hollebrands, K. F. (2003). High school students' understandings of geometric transformations in the context of a technological environment. The Journal of Mathematical Behavior, 22(1), 55-72.

Maharaj, A. (2013). An APOS analysis of natural science students' understanding of derivatives. South African Journal of Education, 33(1), 19. Retrieved from <Go to ISI $>: / / W O S: 000327850500002$

Maharaj, A. (2015). A Framework to Gauge Mathematical Understanding: A Case Study on Linear Algebra Concepts. International Journal of Educational Sciences, 11(2), 144 153. Retrieved from <Go to ISI $>$ ://WOS:000209993700003

Maharaj, A. (2018a). An Investigation into the Preparedness of Teachers to Teach Grade 12 Mathematics: A Case Study. International Journal of Educational Sciences, 21(1-3), 112-123. doi:10.31901/24566322.2018/21.1-3.775

Maharaj, A. (2018b). Students' Understanding of Solving a System of Linear Equations Using Matrix Methods: A Case Study. International Journal of Educational Sciences, 21(13), 124-134. doi:10.31901/24566322.2018/21.1-3.774

Makonye, J. P. (2017). Pre-service mathematics student teachers' conceptions of nominal and effective interest rates. Pythagoras, 38(1), 10. doi:10.4102/pythagoras.v38i1.307

Martin, W., Loch, S., Cooley, L., Dexter, S., \& Vidakovic, D. (2010). Integrating learning theories and application-based modules in teaching linear algebra. Linear Algebra and Its Applications, 432(8), 2089-2099. doi:10.1016/j.laa.2009.08.030

Martinez-Planell, R., Gaisman, M. T., \& McGee, D. (2017). Students' understanding of the relation between tangent plane and directional derivatives of functions of two variables. Journal of Mathematical Behavior, 46, 13-41. doi:10.1016/j.jmathb.2017.02.001

Ministry of National Education [MoNE]. (2009). İlköğretim Matematik Dersi 1-5. Sinıflar Ögretim Programı [Elementary school mathematics curriculum (1-5th grades)]. Ankara: MEB Talim ve Terbiye Kurulu Başkanlığ 1

Ministry of National Education [MoNE]. (2018a). İlköğretim matematik dersi ögretim programı (İlkokul ve Ortaokul 1, 2, 3, 4, 5, 6, 7 ve 8. Siniflar) [Elementary school mathematics curriculum (Grades of 1,2,3,4,5,6,7 and 8]. Ankara: MEB Yayınları

Ministry of National Education [MoNE]. (2018b). Ortaögretim matematik dersi ögretim programı $(9,10,11$ ve 12. Siniflar) [Secondary school mathematics curriculum (Grades of 9, 10, 11 and 12)]. Ankara: MEB Yayınları

Moll, V. F., Trigueros, M., Badillo, E., \& Rubio, N. (2016). Mathematical objects through the lens of two different theoretical perspectives: APOS and OSA. Educational Studies in Mathematics, 91(1), 107-122. doi:10.1007/s10649-015-9639-6 
Moon, K. (2019). Graphs of Two Variable Inequalities: Alternate Approaches to the Solution Test. Mathematics Enthusiast, 16(1-3), 107-126. Retrieved from < Go to ISI $>$ :/WOS:000484167900008

National Council of Teachers of Mathematics [NCTM]. (1989). Curriculum and evaluation standards for school mathematics. USA: National Council of Teachers of Matematics.

National Council of Teachers of Mathematics [NCTM]. (2000). Principles and standards for school mathematics. Reston, VA: National Council of Teachers of Mathematics.

National Council of Teachers of Mathematics [NCTM]. (2014). Principles to actions: Ensuring mathematical success for all. USA: National Council of Teachers of Mathematics, Incorporated.

Ndlovu, Z., \& Brijlall, D. (2016). Pre-service Mathematics Teachers' Mental Constructions of the Determinant Concept. International Journal of Educational Sciences, 14(1-2), 145-156. Retrieved from <Go to ISI >://WOS:000402865300017

Ndlovu, Z., \& Brijlall, D. (2019). Pre-service mathematics teachers' mental constructions when using Cramer's rule. South African Journal of Education, 39(1), 1-13. doi:10.15700/saje.v39n1a1550

Ponte, J. P. d. (1992). The history of the concept of function and some educational implications. The Mathematics Educator, 3-8.

Portnoy, N., Grundmeier, T. A., \& Graham, K. J. (2006). Students' understanding of mathematical objects in the context of transformational geometry: Implications for constructing and understanding proofs. The Journal of Mathematical Behavior, 25(3), 196-207.

Possani, E., Trigueros, M., Preciado, J. G., \& Lozano, M. D. (2010). Use of models in the teaching of linear algebra. Linear Algebra and Its Applications, 432(8), 2125-2140. doi:10.1016/j.laa.2009.05.004

Siyepu, S. W. (2015). Analysis of errors in derivatives of trigonometric functions. International Journal of Stem Education, 2, 16. doi:10.1186/s40594-015-0029-5

Stenger, C., Weller, K., Arnon, I., Dubinsky, E., \& Vidakovic, D. (2008). A search for a constructivist approach for understanding the uncountable set $\mathrm{P}(\mathrm{N})$. Revista Latinoamericana De Investigacion En Matematica Educativa-Relime, 11(1), 93-125. Retrieved from $\leq$ Go to ISI $>$ ://WOS:000264753500004

Trigueros, M., \& Martinez-Planell, R. (2010). Geometrical representations in the learning of two-variable functions. Educational Studies in Mathematics, 73(1), 3-19. doi:10.1007/s10649-009-9201-5

Trigueros, M., \& Oktac, A. (2019). Task design in APOS Theory. Avances De Investigacion En Educacion Matematica(15), 43-56. doi:10.35763/aiem.v0i15.256

Trigueros, M., \& Possani, E. (2013). Using an economics model for teaching linear algebra. Linear Algebra and Its Applications, 438(4), 1779-1792. doi:10.1016/j.laa.2011.04.009

Yanik, H. B., \& Flores, A. (2009). Understanding rigid geometric transformations: Jeff's learning path for translation. The Journal of Mathematical Behavior, 28(1), 41-57.

Yin, R. K. (2018). Case study research and applications: Design and methods (Sixth ed.). Los Angeles, London, New Delhi, Singapore, Washington DC, Melbourne: Sage Publications. 